\title{
The Role of Collaboration between Incumbent Firms and Start-ups on Customers' Adoption of Digital Innovation
}

\author{
Nihal Islam \\ Technische Universität Darmstadt, Germany \\ islam@is.tu-darmstadt.de
}

\begin{abstract}
Due to growing hyper-competition, firms need to create digital innovation in order to remain competitive in the digital era. While start-ups are known as a major source of creativity because they use new technologies to develop digital innovations, incumbent firms are beginning to address the opportunities and challenges of digitalization. Against this backdrop, incumbent firms have become interested in collaborating with start-ups in order to create digital innovation in co-development and offer it to customers. However, insights into costumers subjective stance towards adoption regarding digital innovation that is marketed by incumbent firms and start-ups are absent in the existing research. In light of this, we have analyzed this field based on a qualitative study with 16 interviews with customers. With our results, we contribute to the literature and provide practitioners with valuable insights into how collaboration between incumbent firms and start-ups should be presented to customers of digital innovations.
\end{abstract}

\section{Introduction}

Digital technologies affect firms when entering into new markets that have originally been dominated by others. Thereby, the expertise in digital technologies enables a great competitive advantage and allows for the development of digital products and services with innovative value propositions. As a result, firms like Google or Apple are able to challenge organizations from long-established industries like automotive or banking. For example, by providing a self-driving car, Google has threatened established premium automobile manufacturers like Mercedes or BMW in their core market. Besides that, by offering Apple Pay, Apple provides an alternative to traditional credit card payments. These and many other examples illustrate how IT-oriented firms acting as cross-boundary disruptors evoke change in long-established industries [1]. But it is not only the five largest tech companies (Apple, Google, Microsoft, Facebook, and Amazon)

\author{
Peter Buxmann \\ Technische Universität Darmstadt, Germany \\ buxmann@is.tu-darmstadt.de
}

that are changing the market. Established players who adjust their business models to exploit new opportunities arising from advanced digital technologies can generate significant impact as well. For instance, Deutsche Bank, one of the largest German banks, has established a cross-functional digital business strategy in order to increase customer loyalty through extended customer digital services. Reacting to these developments of digitalization, many incumbent firms try to develop digital innovations. However, in most cases, they are not as innovative as start-ups. On the contrary, due to lack of resources and customer confidence, start-ups face challenges with their digital products and services in the market [2]. Against this background, more and more incumbent firms and start-ups are located to collaborate together. There are already a few incumbent firms beginning to establish structures in which to collaborate with startups. For instance, there are corporate-startup programs, namely, accelerator programs like the accelerator program "Microsoft Ventures" and the newly founded "InnoJam++" event from SAP in cooperation with Volkswagen.

In the digital era, collaboration between incumbent firms and start-ups is a relatively frequent phenomenon in organizational life. However, it still remains unclear whether costumers' subjective stance towards buying decisions regarding digital innovation that is marketed by incumbent firms and start-ups is specific and differs from common product offering. While one stream of literature has discussed several factors affecting the online buying decisions of customers, other research has analyzed the effects of customer trust and risk on online purchase decision-making (see Table 1 in section 2). No study has examined the topic about digital innovation that is offered by incumbent firms and start-ups with regard to acceptance research so far. Thus, we have approached the following research question: How does collaboration between incumbent firms and start-ups influence costumers' subjective stance towards adoption regarding digital innovation? To answer this question, we have conducted 16 interviews with customers. As a result, we have obtained insights into how type of providers influences 
the adoption of digital innovation that is offered by incumbent firms and start-ups in co-creation and, in contrast, by oneself (without collaboration). For instance, we have been able to show that, similarly to other adoptions, trust toward the provider is of the utmost importance in choosing a product or service. Moreover, in particular, we were able to identify that, from the customers' perspective, a digital innovation offered by a start-up in co-creation with an incumbent firm enables the adoption of more than just digital innovation that is offered by an incumbent firm in cocreation with a start-up, as well as digital innovation that is offered by a start-up on its own and an incumbent firm on its own. Against this backdrop, as start-ups often excel in areas where established companies might struggle, taking up impulses from them can provide incumbent firms with an important advantage. Aside from that, start-ups are able to build customer confidence through collaboration with incumbent firms.

This paper is structured as follows: In the next chapter, we provide an overview of the theoretical background and related works. Consecutively, we describe how the qualitative study was designed and the interviews with customers executed. Afterwards, we present the empirical results of our research. Based on this, we have built and present an extended framework of TAM that should represent the theoretical lens under which findings can be investigated in further studies. Finally, we conclude by describing the limitations and avenues for future research.

\section{Theoretical Background and Related Works}

The primary objective of many digitalization efforts in firms is to become more innovative. According to Barnett [3], an innovation is the first use of a scientific invention in an organization. Thereby, an invention may be a new or improved product, process or service [4]. Additionally, Yoo, Henfridsson and Lyytinen [5] define digital innovation as "the carrying out of new combinations of digital and physical components to produce novel products." An example of a digital innovation is the fitness tracking services enabled by Nike's running shoes connected to Apple's mobile devices. The adoptions of customers for an innovative product and service have been broadly researched. Thus, we focused on the technology acceptance model (TAM) that is a widely-used framework in the field of information systems (IS) [6]. TAM makes forecasts for the acceptance of newly introduced technologies. Thus, the aim of the model is to explain determinants of the acceptance of technologies and to structure this in a theoretically well-founded, generalized form so that user behavior can be explained. On the basis of recommendations in previous studies, Davis' model was based mainly on the Theory of Reasoned Action Model, developed by Ajzen and Fishbein [7], [8]. Davis's TAM postulates that the use of technologies such as information systems (actual use) is determined by the attitude toward using (A). The subjective perception of technology is influenced by two main factors: The first factor is the perceived usefulness (PU), which describes the subjective feeling about the use of a technology to increase one's own work performance. Moreover, the perceived ease of use (PEOU), which is the second factor, describes the subjective perception of the user with regard to the simplicity of their own use. According to Davis [6], both the factors PU and PEOU are influenced by external factors not specified in the model, which may include personal attitudes and behavioral patterns, as well as demographic, communicative, and interpersonal aspects. Thereby, the attitude of an individual is not the only factor that determines the use of a technology. behavioral intention (BI), which precedes the use of the technology and determines the future use behavior, is also influenced by the effect that its introduction can have on the performance of the user (PU). Therefore, even if an employee, for example, does not accept an information system, the use probability may increase when he or she recognizes an improvement in his or her work performance.

In addition, there are a number of extensions of the TAM model. To get insights in the existing literature, we have applied a systematic literature research process. In the following, we present our literature research process with a complete review of past research in related works. The literature review that is presented in this study is based on the framework that was developed by Brocke, Simons, Niehaves, Niehaves, Reimer, Plattfaut and Cleven [9]. The focus of the review scope is to identify the relevant research results and theories with the aim of obtaining a broad understanding of the relevant studies [10]. In conducting this literature research process, we used only the English forms of terms and searched the titles, keywords, and abstracts of relevant books, journal articles, and conference papers. The keywords were used to query seven databases: AIS eLibrary (AISeL), ScienceDirect, and EBSCOhost, via the databases ECONLit, Business Source Premier, PsycARTICLES, PsycINFO, and eBook Collection. After filtering and following screening the full texts, we have identified relevant publications that had been published before September 2017. Afterwards, forward and backward searches as proposed by Webster and Watson [11] were conducted by utilizing Thomas Reuters' Web of 
Knowledge and by reviewing the cited references and all relevant sources. Finally, a manageable number of papers remained, which were read in detail with a focus on identified contributions. In the following, the literature is described along with the main findings in terms of relevant insights in the context of the research framework. Accordingly, Table 1 gives an overview of some specific studies on the TAM to illustrate the related research.

\begin{tabular}{|c|c|c|}
\hline Authors & $\begin{array}{l}\text { Research } \\
\text { field }\end{array}$ & Extensions \\
\hline $\begin{array}{l}\text { Barhoumi and } \\
\text { Barhoumi [12] }\end{array}$ & $\begin{array}{l}\text { E-Information } \\
\text { Service }\end{array}$ & $\begin{array}{l}\text { User Satisfaction, } \\
\text { Free Access, } \\
\text { Information } \\
\text { Architecture, } \\
\text { Content Richness, } \\
\text { Policies and Rules, } \\
\text { Publishers' Quality, } \\
\text { Self-efficacy, Task } \\
\text { Technology Fit }\end{array}$ \\
\hline Cho [13] & $\begin{array}{l}\text { Online Legal } \\
\text { Advice } \\
\text { Services }\end{array}$ & $\begin{array}{l}\text { Trust, Perceived } \\
\text { Risk, Compatibility, } \\
\text { Environmental } \\
\text { Conditions }\end{array}$ \\
\hline $\begin{array}{l}\text { Choi and Totten } \\
\text { [14] }\end{array}$ & Mobile TV & Subjective Norms \\
\hline $\begin{array}{l}\text { Featherman and } \\
\text { Pavlou [15] }\end{array}$ & $\begin{array}{l}\text { Online- } \\
\text { Services }\end{array}$ & Risk \\
\hline $\begin{array}{l}\text { Ghazizadeh, } \\
\text { Lee and Boyle } \\
{[16]}\end{array}$ & Automation & Compatibility, Trust \\
\hline $\begin{array}{l}\text { Giovanis, } \\
\text { Binioris and } \\
\text { Polychronopoul } \\
\text { os [17] }\end{array}$ & $\begin{array}{l}\text { Online- } \\
\text { Banking }\end{array}$ & $\begin{array}{l}\text { IT Experience, } \\
\text { Gender, Age, } \\
\text { Compatibility, } \\
\text { Security, Privacy } \\
\text { Risk }\end{array}$ \\
\hline $\begin{array}{l}\text { Kesharwani and } \\
\text { Singh Bisht [18] }\end{array}$ & $\begin{array}{l}\text { Online- } \\
\text { Banking }\end{array}$ & Security, Privacy \\
\hline $\begin{array}{l}\text { Kumar, Bose } \\
\text { and Raghavan } \\
{[19]}\end{array}$ & $\begin{array}{l}\text { Online- } \\
\text { Banking }\end{array}$ & $\begin{array}{l}\text { Security, Privacy, } \\
\text { Access to } \\
\text { Computers and } \\
\text { Internet }\end{array}$ \\
\hline $\begin{array}{l}\text { Lee and Lehto } \\
{[20]}\end{array}$ & $\begin{array}{l}\text { Videoportal, } \\
\text { Procedural } \\
\text { Learning }\end{array}$ & $\begin{array}{l}\text { User Satisfaction, } \\
\text { Content Richness, } \\
\text { Vividness, Self- } \\
\text { Efficacy }\end{array}$ \\
\hline $\begin{array}{l}\text { Park, Son and } \\
\text { Kim [21] }\end{array}$ & $\begin{array}{l}\text { Web-based } \\
\text { Training }\end{array}$ & $\begin{array}{l}\text { Enjoyment, } \\
\text { Computer Anxiety, } \\
\text { Social Influence, } \\
\text { Organizational } \\
\text { Support, } \\
\text { Information } \\
\text { Quality, System } \\
\text { Quality }\end{array}$ \\
\hline Pavlou [22] & E-Commerce & $\begin{array}{l}\text { Trust, Perceived } \\
\text { Risk }\end{array}$ \\
\hline $\begin{array}{l}\text { Pikkarainen, } \\
\text { Pikkarainen, }\end{array}$ & $\begin{array}{l}\text { Online- } \\
\text { Banking }\end{array}$ & $\begin{array}{l}\text { Perceived } \\
\text { Enjoyment, }\end{array}$ \\
\hline
\end{tabular}

\begin{tabular}{|l|l|l|}
\hline $\begin{array}{l}\text { Karjaluoto and } \\
\text { Pahnila [23] }\end{array}$ & $\begin{array}{l}\text { Security, Privacy, } \\
\text { Information }\end{array}$ \\
\hline $\begin{array}{l}\text { Son, Park, Kim } \\
\text { and Chou [24] }\end{array}$ & $\begin{array}{l}\text { Mobile } \\
\text { Computing }\end{array}$ & $\begin{array}{l}\text { User Satisfaction, } \\
\text { Perceived } \\
\text { Performance }\end{array}$ \\
\hline $\begin{array}{l}\text { Tung, Chang } \\
\text { and Chou [25] }\end{array}$ & E-Logistics & $\begin{array}{l}\text { Trust, Perceived } \\
\text { Financial Cost, } \\
\text { Compatibility }\end{array}$ \\
\hline $\begin{array}{l}\text { Tung, Lee, } \\
\text { Chen and Hsu } \\
\text { [26] }\end{array}$ & $\begin{array}{l}\text { Customer } \\
\text { Relationship } \\
\text { Management }\end{array}$ & $\begin{array}{l}\text { Trust, } \\
\text { Compatibility, } \\
\text { Perceived Financial } \\
\text { Cost }\end{array}$ \\
\hline $\begin{array}{l}\text { Wu and Chen } \\
\text { [27] }\end{array}$ & $\begin{array}{l}\text { Online- } \\
\text { Services }\end{array}$ & $\begin{array}{l}\text { Trust, Perceived } \\
\text { Belief Control, } \\
\text { Subjective Norm }\end{array}$ \\
\hline
\end{tabular}

Table 1. Overview of some specific studies on the TAM.

It can identify the following modification streams in the literature: a) an extension via factors from other models, such as a subjective norm, perceived behavioral control, and self-efficacy, as well as extensions in order to examine alternative factors taken from the theory of diffusion of innovations - for instance, feasibility, compatibility, visibility, or proof of results; b) analysis of external variables, such as demographic factors and the personal relations between the simplicity of use and the perceived usefulness and their explications; c) studies that examine the relevance of the TAM for specific situational applications (a particular type of software, for example).

Taking a closer look at studies identified, the focus investigation was trust in providers [28-31]. Thereby, trust is a continual assessment and reassessment of risks and benefits [32]. There are exist trust factors in different dimensions. For example, from perspective of individual trust, there are seven new trust factors and one sub-factors which are associated with the main factors [33]. However, trust is not only the basis of adoption; there is also the prerequisite for a customer to opt to purchase from online traders. Against this backdrop, providers of digital products and services have to reduce the previously described risk and uncertainty of the customer through trust building [34, 35]. For this purpose, they primarily provide the website as a central link to the customer. In addition to the aspect of establishing trust with the customer, this also has technological attributes that affect potential customers [36].

In summary, the results of the literature review can be synthesized as follows: The factor "trust" is one of the most frequently identified factors in the existing literature. The factors identified in the literature have 
subsequently been examined with respect to their interdependency and their relation to their research field of interest. Furthermore, the literature findings show that most of the publications presented above deal with adoption of digital products and services. However, the identified publications do not focus on digital innovation that has been created and offered by incumbent firms and start-ups. Against this background, the literature evaluation has led to potential future research directions. A better understanding of customers' adoption regarding digital innovation is relatively under-explored in the existing literature. An investigation in this field is of special interest to the current research. By bringing together the observations described above, our research addresses the following question: How does collaboration between incumbent firms and start-ups influence costumers' subjective stance towards adoption regarding digital innovation? Against this background, in the following section, we have evaluated the findings in the related literature via statements by customers interviewed, to obtain new insights regarding digital innovations. Then, we discuss the compiled findings from the interviews and literature review.

\section{Qualitative Study}

As we wanted to identify how collaboration between incumbent firms and start-ups influences the adoption of digital innovation that is created by incumbent firms and start-ups, we decided to conduct a qualitative study. This qualitative approach allowed us to analyze the relationships among the existing constructs in detail and to identify new constructs. In the following, research design, data collection process, and data analysis are described in detail.

\subsection{Research Design and Data Collection}

Despite numerous studies, there are no contributions to the research approach that investigate the adoption process of digital innovations that are offered by startups and incumbent firms from a customer perspective. The analysis of the acceptance of different technological products and services is mainly based on quantitative methods. While they are generally wellsuited to existing theories, their contribution is limited when it comes to the formation of new constructs. It is apparent that existed quantitative studies aimed at the interrelationships between constructs and variables. In this process, the influences of certain variables, such as, for example, trust in acceptance, or already known connections are examined in detail. On the contrary, qualitative data are generally not used for exploration.
Thus, the present paper is an example of the study of the acceptance of digital innovation and shows that this qualitative approach leads to a new construct. For this purpose, we concentrate on interviews with customers of different age groups. Thereby, digital natives are especially interesting, as they already have solid experiences in digital products and services. The participants in the study were selected according to their experience with using digital innovations. We chose to conduct semi-structured interviews. This ensured that all the interviews covered the main topics. At the same time, it allowed for the peculiarities of the respective customers' contexts to be addressed [37, 38]. Furthermore, we used a standardized guideline for each interview, which was developed by following the guidelines provided by Mayring [39]. The interview questions were partially related to the factors of the TAM framework. The interviews were conducted in the period from April to September 2017. In total, the sample is comprised of 16 interviews (see Table 2).

\begin{tabular}{|c|c|c|c|}
\hline \multicolumn{5}{|c|}{ Interviewees } \\
\hline ID & Gender & $\begin{array}{c}\text { Experience of Using } \\
\text { in Field }\end{array}$ & Age Group \\
\hline \hline I-01 & female & Mobile Payment & $18-30$ \\
\hline I-02 & female & Data Analysis & $18-30$ \\
\hline I-03 & male & eSharing & $18-30$ \\
\hline I-04 & female & IT Security & $18-30$ \\
\hline I-05 & male & eSharing & $18-30$ \\
\hline I-06 & male & Data Analysis & $18-30$ \\
\hline I-07 & male & eSharing & $18-30$ \\
\hline I-08 & female & Mobile Payment & $18-30$ \\
\hline I-09 & male & Mobile Payment & $31-43$ \\
\hline I-10 & female & Data Analysis & $31-43$ \\
\hline I-11 & female & eSharing & $31-43$ \\
\hline I-12 & female & Data Analysis & $31-43$ \\
\hline I-13 & male & eSharing & $>44$ \\
\hline I-14 & female & IT Security & $>44$ \\
\hline I-15 & male & Data Analysis & $>44$ \\
\hline I-16 & male & Mobile Payment & $>44$ \\
\hline
\end{tabular}

Table 2. Overview of customers interviewed.

All the interviewees already had experience in digital innovations, and most of them were digital natives. Participants were invited by e-mail to take part in a semi-structured interview in order to share their views of the attitude toward using of digital innovations offered by start-ups, incumbent firms, or by joint startups and incumbent firms. Aside from that, the participants were to be given insights into their perceptions of digital innovation offered by a start-up in collaboration with an incumbent firm and an incumbent firm in collaboration with a start-up. In 
total, five examples of digital innovations were presented to interviewees.

The interviews were held in non-public spaces and lasted, on average, 35 minutes each. All interviews were tape-recorded. For easier analysis, the recorded material was transcribed. This process resulted in 192 pages of transcripts.

\subsection{Data Analysis}

The interview data was analyzed using the qualitative content analysis technique developed by Mayring [39]. In the first steps, among other things, the empirical background and formal characteristics of the material were determined. These steps have already been described in the previous section. Based on the introductory research question, we aimed to reduce the raw material to a category system. Against this background, the coding was divided into the following major steps: First, the individual statements were summarized in paraphrased and generalized form. Afterwards, we reduced these into codes and checked whether the codes could be summarized in relevant categories. Thereby, each code was related to a category when the term, synonym, or description was mentioned by the customers interviewed. Finally, the relation among different categories could be investigated.

\section{Empirical Results and Discussion of Findings}

Presenting our results, we want to illustrate the different relevant statements identified in our analysis. According to the existing literature, by taking a closer look at the subjective state of adoptions of the customers interviewed, we could identify that trust toward the provider was the most frequently mentioned factor. Moreover, all participants reviewed the examples of digital innovations, and all found them innovative. Thereby, in line with reports from the media, most interviewees considered start-ups as a very important contributor to innovative effectiveness for customers, as the following statement emphasizes: "Normally, start-ups have an innovative spirit. To me, they get my attention when the digital innovation is offered by a start-up as if is offered by an incumbent firm" (I-02). While the customers see potential of digital innovation of start-ups, they are also aware of the associated risks. Many interviewees state that they first need to develop a feeling for these new, innovative products and services. Thus, the analysis of our interview data shows that digital innovations of incumbent firms and start-ups are rated more positively by customers interviewed. For this reason, incumbent firms should think about whether collaboration with a start-up would be beneficial. A customer interviewed summarized: "There are three types of incumbent firms; it depends on their primary business objectives. Would they like to be an innovation leader, quality leader, or cost leader? Nowadays, they should be innovation leaders" (I-11). In order to become an innovation leader, incumbent firms need to consider and exploit the potential in collaboration with start-ups. From the customers' perspective, a digital innovation that is offered by joint start-ups and incumbent firms are gaining more attention: "[...] they (digital innovations) find more acceptance, as we (customers) have the feeling the product should be useful and mature" (I-11). Almost all of the interviewees would have preferred a digital innovation that was offered by incumbent firms and start-ups together. Thus, the primary perception of the interviewees was to distinguish digital innovation through the focus on the providers. The following quotation highlights this: "I am very interested in buying digital innovation with the focus on the customer side and differentiation in the marketplace that is co-developed by incumbent firms and start-ups “ (I-08). In particular, a digital innovation that is offered by a start-up with reference to collaboration with an incumbent firm has a bigger effect on adoptions than a digital innovation that is offered by an incumbent firm with reference to collaboration with a start-up.

Based on our empirical results, the following hypotheses could be derived from the qualitative interview data:

(1) There is a relationship between the provider of a digital innovation and the adoption of the digital innovation by the users.

(2) The collaboration between incumbent firms and start-ups has a positive effect on the adoption process of consumers.

Accordingly, we could determine that the TAM model can be extended by a new construct. This construct reflects the influence of the type of provider, such as an incumbent firm or a start-up for a digital innovation, on the adoption. In order to structure our empirical results of research, we are able to provide a framework based on TAM by Davis [6]. This extended framework is shown in Figure 1. 


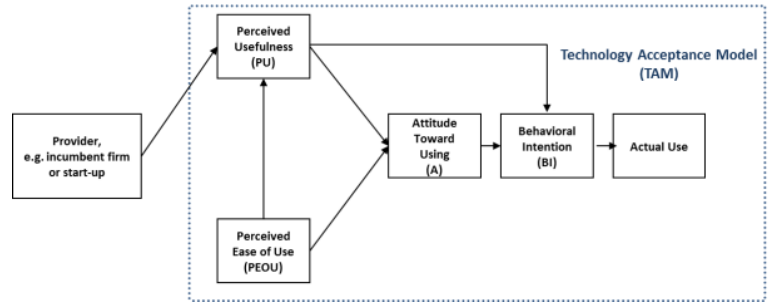

Figure 1. Extended framework based on TAM.

\section{Conclusion, Implications, and Future Research}

Digitalization is the key driver of global, social, and economic developments. In the wake of these developments, firms are being forced to reorganize, and previously functioning business models need to be changed profoundly. Thereby, the simple digitization of classical business processes does not evoke the expected benefit. Rather, the real added value is the creation of innovativion enabled by new digital technologies. However, incumbent firms are facing various challenges when it comes to transforming their classical business model into a digital one. Thereby, on the one hand, start-ups challenge the incumbent firms with new solutions and business models and, on the other hand, incumbent firms can provide important impulses from start-ups to pursuit digitalization in their organizations. Against this backdrop, collaboration between incumbent firms and start-ups gain in importance. However, the perspective of customers on collaboration have not considered until now. In this paper, TAM is intended to describe the user acceptance of the digital innovation of incumbent firms and startups. As already explained, no study has examined this topic with regard to acceptance research so far. Thus,

\section{References}

[1] R.A. Burgelman, A.S. Grove, Cross-boundary disruptors: powerful inter-industry entrepreneurial change agents, (2007).

[2] N. Islam, P. Buxman, N. Eling, Why should Incumbent Firms jump on the Start-up Bandwagon in the Digital Era?A Qualitative Study, (2017).

[3] H.G. Barnett, Innovation: The Basis of Cultural Change, McGraw-Hill, New York, USA, 1953.

[4] E.M. Rogers, Diffusion of innovations, Free PressNew York, 1995. an extension of the original model was necessary for this particular application. Against this background, we have investigated how collaboration affects the customers' adoption of digital innovation. The present paper provides insights that can guide incumbent firms' collaboration efforts with start-ups. In detail, our study makes three major contributions: First, we have identified a new factor influencing customers' adoption regarding digital innovation. Second, we provide guidance for practitioners who want to establish collaboration projects forward and offer digital products and services. Third, we have marked out a field for future investigation and provide our key finding as a basis for research discussion.

As any study, our qualitative research features several limitations. However, these same limitations provide interesting avenues for further research. By relying on a sample of customers from different age groups, we were able to obtain a holistic view of adoption of digital innovation. However, in our interviews, we covered a wide variety of customers. However, it might be interesting to differentiate among more people. Depending on the respective experiences, in a quantitative study, the finding might be validated by indications of more customers. Besides that, due to the interpretive nature of our research, the results we have described represent the sense-making process of the researchers. Subjective personal judgments cannot be ruled out completely, even though we took great care to reflect the subjects' opinions as correctly as possible. Moreover, it would be interesting to perform an experiment as well. These analyses might face different issues when testing a given sample under real conditions. In this context, for future studies, it might be compelling to have a look at concrete adaption process regarding digital innovations.

[5] Y. Yoo, O. Henfridsson, K. Lyytinen, Research commentary - the new organizing logic of digital innovation: an agenda for information systems research, Information systems research, 21 (2010) 724-735.

[6] F.D. Davis, Perceived usefulness, perceived ease of use, and user acceptance of information technology, MIS quarterly, (1989) 319-340.

[7] I. Ajzen, M. Fishbein, Attitude-behavior relations: A theoretical analysis and review of empirical research, Psychological bulletin, 84 (1977) 888. 
[8] I. Ajzen, M. Fishbein, Understanding attitudes and predicting social behaviour, (1980).

[9] J.v. Brocke, A. Simons, B. Niehaves, B. Niehaves, K. Reimer, R. Plattfaut, A. Cleven, Reconstructing the giant: on the importance of rigour in documenting the literature search process (2009).

[10] H.M. Cooper, Organizing knowledge syntheses: A taxonomy of literature reviews, Knowledge, Technology \& Policy, 1 (1988) 104-126.

[11] J. Webster, R.T. Watson, Analyzing the past to prepare for the future: Writing a literature review, MIS quarterly, (2002) xiii-xxiii.

[12] C. Barhoumi, C. Barhoumi, User acceptance of the einformation service as information resource: A new extension of the technology acceptance model, New Library World, 117 (2016) 626-643.

[13] V. Cho, A study of the roles of trusts and risks in information-oriented online legal services using an integrated model, Information \& Management, 43 (2006) 502-520.

[14] Y.K. Choi, J.W. Totten, Self-construal's role in mobile TV acceptance: Extension of TAM across cultures, Journal of Business Research, 65 (2012) 1525-1533.

[15] M.S. Featherman, P.A. Pavlou, Predicting e-services adoption: a perceived risk facets perspective, International journal of human-computer studies, 59 (2003) 451-474.

[16] M. Ghazizadeh, J.D. Lee, L.N. Boyle, Extending the Technology Acceptance Model to assess automation, Cognition, Technology \& Work, 14 (2012) 39-49.

[17] A.N. Giovanis, S. Binioris, G. Polychronopoulos, An extension of TAM model with IDT and security/privacy risk in the adoption of internet banking services in Greece, EuroMed Journal of Business, 7 (2012) 24-53.

[18] A. Kesharwani, S. Singh Bisht, The impact of trust and perceived risk on internet banking adoption in India: An extension of technology acceptance model, International Journal of Bank Marketing, 30 (2012) 303-322.

[19] V. Kumar, S. Bose, P. Raghavan, Extension of Technology Adoption Model (TAM) Intention to Use Internet Banking: Evidence from India, International Journal of Finance \& Policy Analysis, 3 (2011).

[20] D.Y. Lee, M.R. Lehto, User acceptance of YouTube for procedural learning: An extension of the Technology Acceptance Model, Computers \& Education, 61 (2013) 193-208.

[21] Y. Park, H. Son, C. Kim, Investigating the determinants of construction professionals' acceptance of web-based training: An extension of the technology acceptance model, Automation in Construction, 22 (2012) 377-386.

[22] P.A. Pavlou, Consumer acceptance of electronic commerce: Integrating trust and risk with the technology acceptance model, International journal of electronic commerce, 7 (2003) 101-134.

[23] T. Pikkarainen, K. Pikkarainen, H. Karjaluoto, S. Pahnila, Consumer acceptance of online banking: an extension of the technology acceptance model, Internet research, 14 (2004) 224-235.

[24] H. Son, Y. Park, C. Kim, J.-S. Chou, Toward an understanding of construction professionals' acceptance of mobile computing devices in South Korea: An extension of the technology acceptance model, Automation in construction, 28 (2012) 82-90.

[25] F.-C. Tung, S.-C. Chang, C.-M. Chou, An extension of trust and TAM model with IDT in the adoption of the electronic logistics information system in HIS in the medical industry, International journal of medical informatics, 77 (2008) 324-335.

[26] F.-C. Tung, M.S. Lee, C.-C. Chen, Y.-S. Hsu, An extension of financial cost and TAM model with IDT for exploring users' behavioral intentions to use the CRM information system, Social Behavior and Personality: an international journal, 37 (2009) 621-626.

[27] L. Wu, J.-L. Chen, An extension of trust and TAM model with TPB in the initial adoption of on-line tax: an empirical study, International Journal of Human-Computer Studies, 62 (2005) 784-808.

[28] X. Li, T.J. Hess, J.S. Valacich, Why do we trust new technology? A study of initial trust formation with organizational information systems, The Journal of Strategic Information Systems, 17 (2008) 39-71.

[29] I. Benbasat, W. Wang, Trust in and adoption of online recommendation agents, Journal of the association for information systems, 6 (2005) 4.

[30] D.H. McKnight, V. Choudhury, C. Kacmar, Developing and validating trust measures for e-commerce: An integrative typology, Information systems research, 13 (2002) 334-359.

[31] D.H. McKnight, V. Choudhury, C. Kacmar, The impact of initial consumer trust on intentions to transact with a web site: a trust building model, The Journal of Strategic Information Systems, 11 (2002) 297-323.

[32] X. Cheng, S. Fu, D. Druckenmiller, Trust development in globally distributed collaboration: A case of US and Chinese mixed teams, Journal of Management Information Systems, 33 (2016) 978-1007. 
[33] X. Cheng, L. Macaulay, Exploring individual trust factors in computer mediated group collaboration: a case study approach, Group Decision and Negotiation, 23 (2014) 533-560.

[34] R.M. Morgan, S.D. Hunt, The commitment-trust theory of relationship marketing, The journal of marketing, (1994) 20-38.

[35] S.L. Jarvenpaa, N. Tractinsky, L. Saarinen, Consumer trust in an internet store: a cross-cultural validation, Journal of Computer-Mediated Communication, 5 (1999) 0-0.

[36] D. Gefen, E. Karahanna, D.W. Straub, Trust and TAM in online shopping: an integrated model, MIS quarterly, 27 (2003) 51-90.

[37] R.K. Yin, Case study research: Design and methods, Sage publications2013.

[38] K. Neuendorf, The content analysis guidebook Sage Publications, Inc, Library of Congress. CA: United States, 2002.

[39] P. Mayring, Qualitative content analysis: theoretical foundation, basic procedures and software solution, (2014). 